\title{
ENG Gene
}

National Cancer Institute

\section{Source}

National Cancer Institute. ENG Gene. NCI Thesaurus. Code C28573.

This gene in involved in endothelial cell proliferation. 